\title{
Matching Analysis of Output Power and Electricity Load of Typical PV System
}

\author{
Rui $\mathrm{Hu}^{\mathrm{a}}$, Xudong $\mathrm{Xu}{ }^{\mathrm{b}}$ \\ Shanghai Power Industrial \& Commercial Co. Ltd. \\ Economist, Shanghai, China \\ àH.2002@163.com, bsepc_xuxudong@126.com
}

\author{
Yingjie Tian \\ State Grid Shanghai Electric Power Research Institute, \\ Senior Engineer, Shanghai, China \\ tianyj@sh.sgcc.com.cn
}

\author{
Yifang Li \\ Zhejiang University, Postgraduate, Hangzhou, China \\ yifang20100707@163.com
}

\begin{abstract}
The major content of this paper is to study the operation data of a demonstration program in Shanghai to match the system's output power curves with power load in practical through its different installed capacity. Efforts was made to find out a more optimized scheme for PV system's capacity configuration. It is intended to improve the whole system's economics, decrease the buildings' energy consumption, provide a reference standard for the PV system's construction .
\end{abstract}

Keywords-photovoltaic cells; output power curves; power load; power matching; economy

\section{INTRODUCTION}

Owing to the development of photovoltaic relevant equipment and the Maturation of the production technology in recent years, The cost of photovoltaic power generation has been decreased while the production cost decreasing and conversion efficiency improving. And it is indicated to decrease $0.04-0.08 \$ / \mathrm{kWh}$ in 2020 compared to today ${ }^{[1]}$. The Frost\&Sullivan anticipates that the total market value of photovoltaic generation will increase to 1370.2 billion in 2020 from 589.4 billion at present ${ }^{[2]}$. This offers an opportunity for international market back to PV system ignored once because of the high cost.

The incentive policy has helped make photovoltaic industry more active. However, large ground-scale photovoltaic power stations were influenced by many factors due to the great affection by the industry development strategy put up earlier, such as great lose resulted by the limitation on electric, competitive pressure by the limitation on construction scale through national policy.

In contrast, the small-scaled distributed PV program shows some advantages on the problems mentioned above. In the PV system , non-utility generation and in-situ electric energy consumption are the first consideration with much less sensitivity. National Energy Bureau issued a notice $<<$ Notice on the implementation scheme of the construction of photovoltaic power generation in 2015>> indicating that construction scale will not be restricted for distributed roof PV system and all of in-sute electric energy PV programs ${ }^{[3]}$, effectively avoiding the excessive competition in photovoltaic industry.
The ultimate objective is to optimize the installed capacity configuration of PV cells. This task analyzed a distributed PV system in Shanghai, studied on the rate of power load changing, the output power of photovoltaic array, the relationship between PV installed capacity and power load.

\section{The Demonstration ProJect}

The demonstration program is located in an 23-floor office building in city center. The building's area is about $30000 \mathrm{~m}^{2}$. There is a photovoltaic array Composed of 128 Polysilicon PV battery components on the roof. The installed capacity of battery is about $30 \mathrm{kWp}$. A three-phase inverter helps the photovoltaic array access into the $380 \mathrm{~V}$ power distribution system.

The generated energy is designed $30000 \mathrm{kWh}$ per year while its cumulative generated energy is $10849.2 \mathrm{kWh}$ in the period of from the Oct 2014 to Sec 2015.

\section{Output Power Of The Photovoltaic System}

\section{A. Influencing Factors of Photovoltaic System Output} Power

The output power of the PV system was influenced by its internal factors and the external factors. Taking the two factors into account at the same time, the Output power characteristics of the PV system can be obtained.

- Internal factors: The internal factors are mainly referred to the influencing factors of the PV system's self-collocating, including photovoltaic cells' voltampere characteristic, electric equipment and the characteristic of the electric circuits. The internal factors mentioned keeps invariant, determining the basic output power characteristic. For two PV system, their output power characteristic will be the same if their configurations are same.

- External factors: The external factors are referred to the influence factors come from outside, which mainly include the light intensity and the temperature $^{[4]}$ (Figure.1, Figure.2) . These factors mentioned above will affect its voltage characteristics, and the affect changes with the time. 


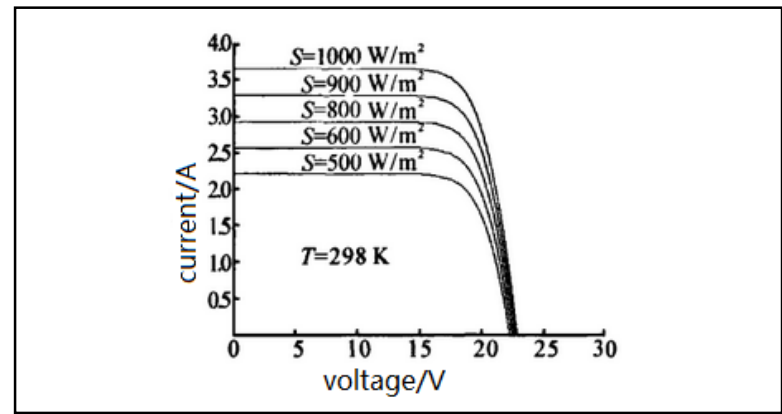

Figure 1. Influence of different light intensity on photovoltaic cells' volt-ampere characteristic

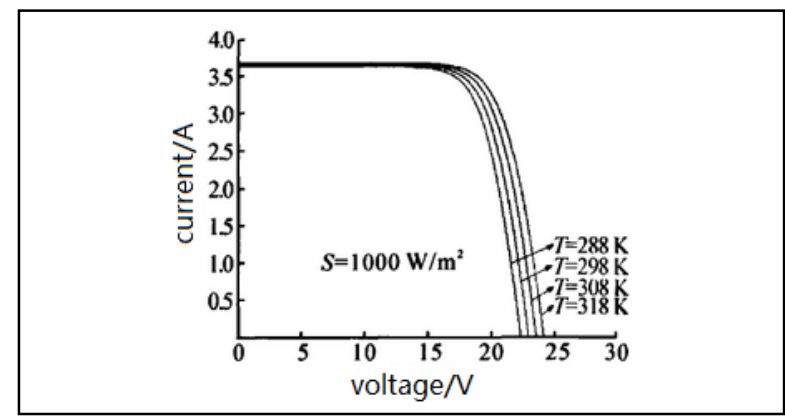

Figure 2. Influence of different temperature on photovoltaic cells' voltampere characteristic

\section{B. Typical Photovoltaic System Output Power Curve}

- The optimal power curve

To study on the rationality of matching between photovoltaic cells' installed capacity and power load for users, recording the amount of electricity's generation and consumption only is not enough. In order to study the relationship of electricity generation and the consumption more concretely, finding out the optimal power curve is very important.

The general way to draw the curve of photovoltaic output power has two processes. First, recording the best output power data of PV system along with different light intensity, rated voltage under $25^{\circ} \mathrm{C}$. Then, getting the data in different periods a day by the same method and draw the curve at the PV system's site.

However, The result of practical operation shows that the PV system is not always working at the point of its best output power, so the actual output power and the record data are not anastomose completely. Besides, there are some difficult in gathering real-time data about the solar radiation and the best photovoltaic cells' power. A simplified method is put forward, taking the typical power curve instead of the best power curve.

We collected the output power data of the photovoltaic array in this system from Oct 2014 to Feb 2015. According to the analysis of the record data, we choose the output power curve which shows the whole system power generation in sunny day. The ordinate express $1 \mathrm{kWp}$ photovoltaic cells output power in every period(Figure.3), comparing the typical output power curve with the best output power curve, although the power value at each time point and the generate electricity capacity of per day are both little lower, but they are very similar to the real system .

- Relationship of the best power curve and annual power generation

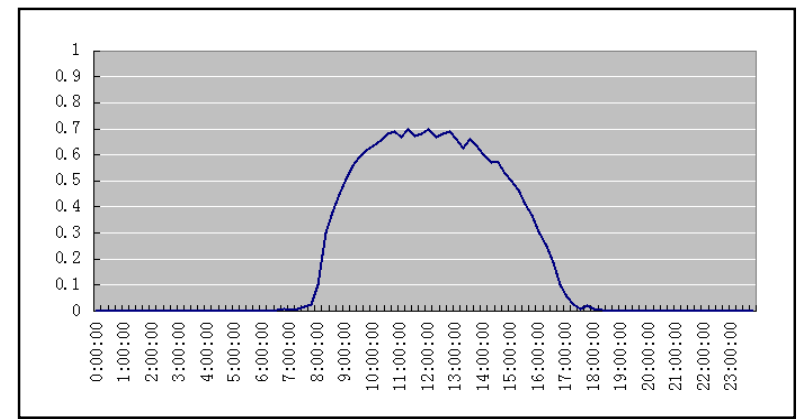

Figure 3. Typical output power curve of PV system

The result of experiments shows that generated energy is relatively high in clear day, averaging $80 \mathrm{kWh}$, the peak value can reach the maximum more over 140kWh (Figure.4). Comparatively speaking, it decreases significantly in rainy day, averaging $20 \mathrm{kWh}$. It changes relatively greatly in cloudy condition, varying from $20 \mathrm{kWh}$ to $100 \mathrm{kWh}$ uncertainly according to the actual conditions of that day. The photovoltaic cells' output power curves were significantly different in the different weather conditions. Typical output power curves in three different situations were selected which were clear day, cloudy day and rainy day(Figure.5). The output power curve in clear day was plumper, but due to the movements of clouds, it was unstable and uneven and kept the lowest level on rainy day.

The total generated energy amount of this PV system was 10849.2kWh from Oct 2014 to Feb 2015. The total generated energy amount obtained was $26224.8 \mathrm{kWh}$ in the whole year according to these data. As the typical power curve represents the situation of clear day, the loss because of the bad weather were ignored. Just in this case, it can reach up to $52742.5 \mathrm{kWh}$. The difference between two results was almost one fold.

Shanghai experiences a subtropical monsoon climate whose average annual rainfall is plentiful. In the 150 days from Oct 2014 to Feb 2015, there were 61 clear days, 49 cloudy days and 40 rainy days. Under these complicated conditions, firstly, a certain ratio between typical power curve and electricity load was made. About the generated energy, estimated by typical power curve and then shall be multiplied by a empirical weather coefficient $\mathrm{K}$, make sure there is only a less differences between the theoretical calculations and production data.

$\mathrm{K}=\mathrm{actual}$ annual power generation/estimated annual generated energy.

The annual generated energy designed replace the actual data cannot be collected. In this PV system, system annual generated energy designed is $30000 \mathrm{kWh}$, the estimated annual generated energy is about $52742.5 \mathrm{kWh}$, empirical weather coefficient is $56.88 \%$. 


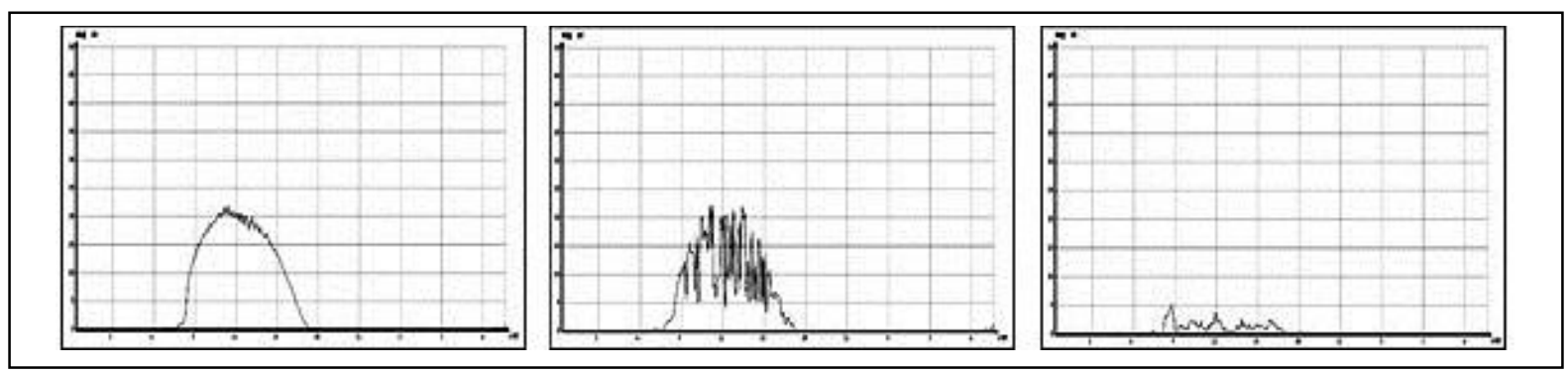

Figure 4. Daily power generation on different weather conditions

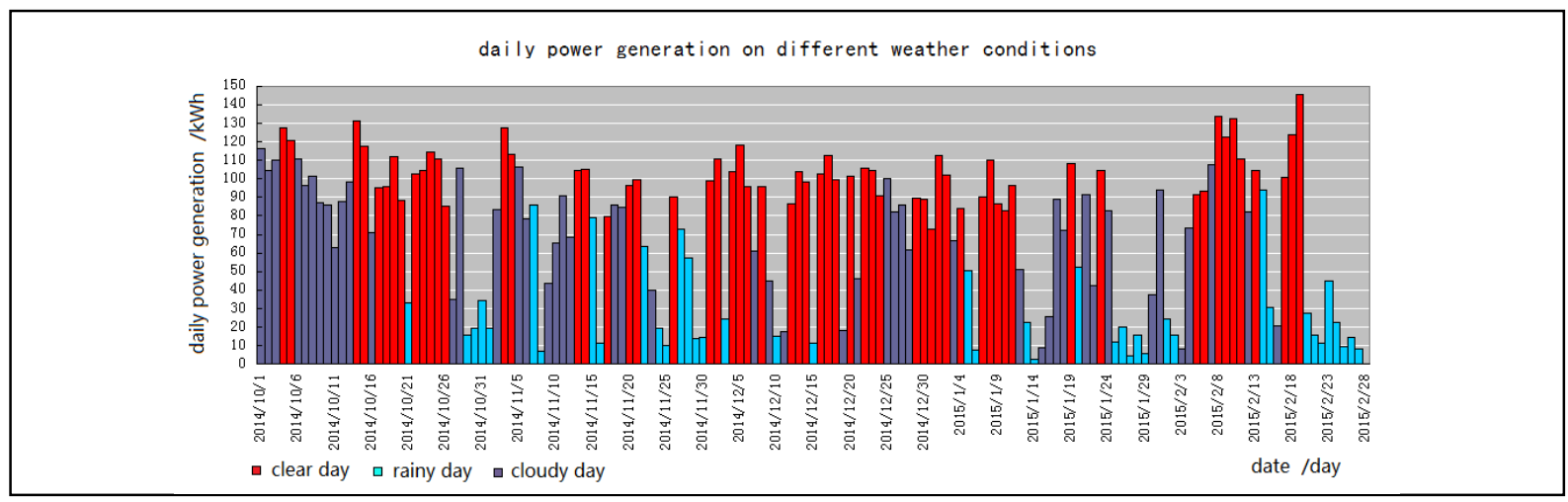

Figure 5. Output power curve of photovoltaic cells in different weather conditions

\section{VARIATION CHARACTERISTICS OF POWER CONSUMPTION LOAD}

\section{A. Characteristics of Power Consumption Load}

A power quality detecting system was used to gather experimental data in this demonstration project. It was found that power consumption load has a certain regularity according to the daily load curve of electricity consumption from Oct 2014 to Feb 2015.

We get curves of power consumption load data of 150 days in one data acquisition cycle, stack them to display in one graph, classify them into three situations based on the curve shape(Figure.6).

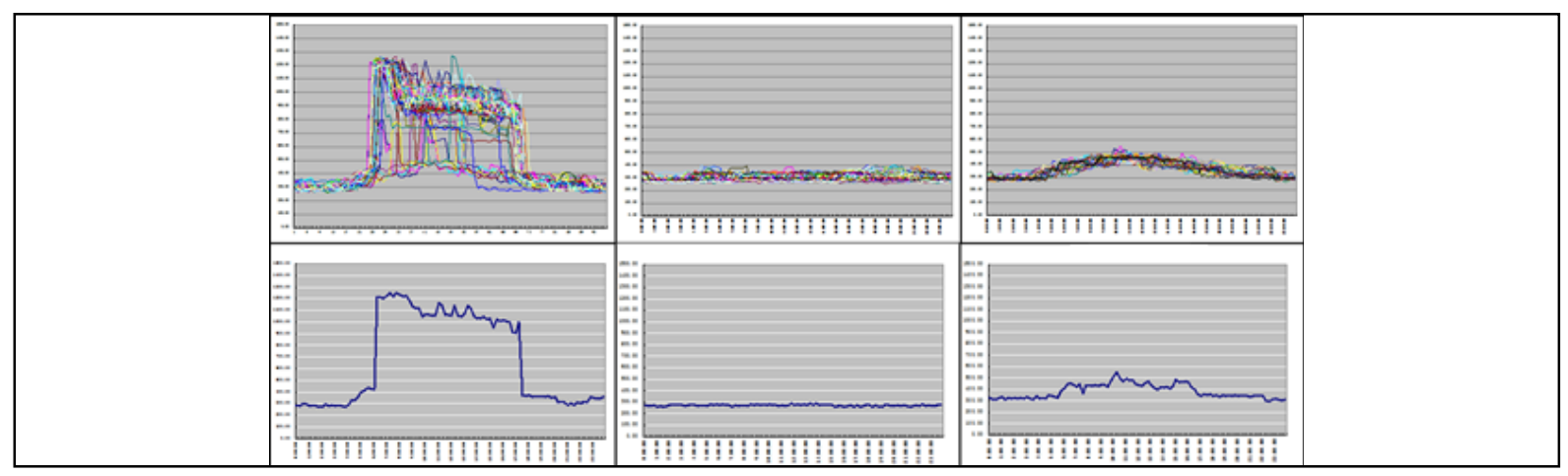

Figure 6. Three different curve of daily electricity load

- $\quad$ The first case left one in the graph, the time was 67 days.

This situation happens in all working day from the beginning of December till February of next year, the power load curves show that using electric power was higher in the period from 6:00 in the morning till 18:00 in the afternoon. Load's increasing mainly includes the air conditioning load, lighting and socket based on the analysis on readings of partial measuring electric meter. Lighting was the major power consumption load without air conditioner in all other time, the system load was lower of this time.

- The second case middle in the graph, the time was 51 days 
This situation happens in all the holidays. Power load reached the lowest level these days , kept invariant all day. The lighting load was the mainly part of lowest load maintained.

- The third case right in the graph, the time was 33 days

This situation mainly happened from the beginning of October to the beginning of Dec, power load increased a little from 6:00 in the morning till 18:00 in the afternoon. Main factor are socket and system load which was low without air conditioners.

\section{B. Power Consumption Load Characteristics of Business Building}

Three characteristics of power consumption load was summarized as follows(Figure.7):

- Daily power load characteristic can be depended on working cycle and working time. It remained a high level in the working time while decreased to the lowest point out of the working time.

- It was affected by season for air conditioner is a important factor of system power load.

- There are some lighting equipment, elevators of equipment to keep the lowest power load on holiday.

\section{POWER CONSUMPTION LOAD ANd PHOTOVOLTAIC INSTALLED CAPACITY}

After the text edit has been completed, the paper is ready for the template. Duplicate the template file by using the Save As command, and use the naming convention prescribed by your conference for the name of your paper. In this newly created file, highlight all of the contents and import your prepared text file. You are now ready to style your paper.

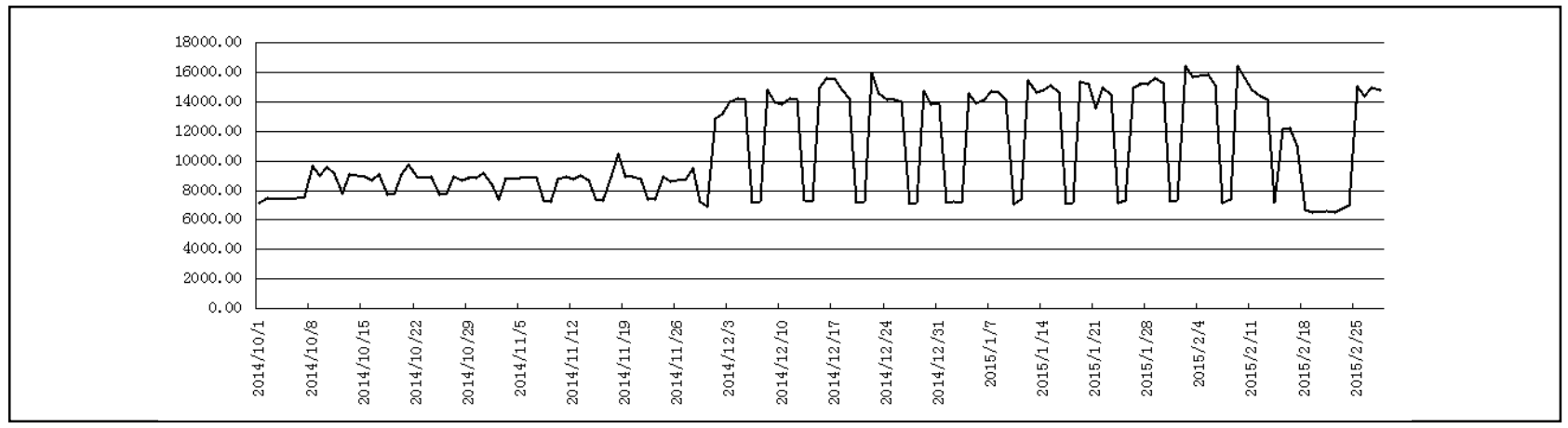

Figure 7. Daily cumulative power consumption statistical curve

\section{A. Load Type Components}

Power change will increase with equal ratio at each time point of generated power curve while the installed capacity for every $1 \mathrm{kWp}$ increased. Therefore, we attempt to calculate the area under power consumption curve to get the installed capacity for different conditions of power consumption load.

Making ratio of typical output power curve(Figure.3) to power consumption curve(Figure.6), the installed capacity was found out to be $1530 \mathrm{kWp}$ (high load), $630 \mathrm{kWp}$ (low load), 390kWp(holiday) separately(Figure.8).

With the same method, making ratio of the area of the power load curve to generated energy curve and power consumption curve to estimate the power generated for the three type installed capacity(Figure.8) as follows:

- Do not increasing photovoltaic cells' number until installed capacity improved up to $1530 \mathrm{kWp}$, system would work under high load. Under this circumstance, the annual generated energy amount would be about $1529202 \mathrm{kWh}$ in which generation amount was about $498951 \mathrm{kWh}$, account for $31.9 \%$ of total annual generated energy.
- Do not increasing photovoltaic cells' number until installed capacity improved up to $630 \mathrm{kWp}$, system would work under low load. Under this circumstance, the annual generated energy amount would be about $629820 \mathrm{kWh}$ in which generation amount was about $53745 \mathrm{kWh}$, account for $8.5 \%$ of total annual generated energy.

- Do not increasing photovoltaic cells' number until installed capacity improved up to $390 \mathrm{kWp}$, system would work on holidays. Under this circumstance, the annual generated energy amount would be about $389796 \mathrm{kWh}$ in which generation amount was only 82kWh, nearly no generated energy from the system.

The relationship between installed capacity and annual generated energy, generation amount and the total generated energy were obtained (Figure.9). The relationship between installed capacity and annual generated energy is linear (Figure.10). There is linear relationship between annual generated energy and generated amount (Figure.11). Figure highlights represent three kinds of installed capacity:390kWp、630kWp、1530kWp. 


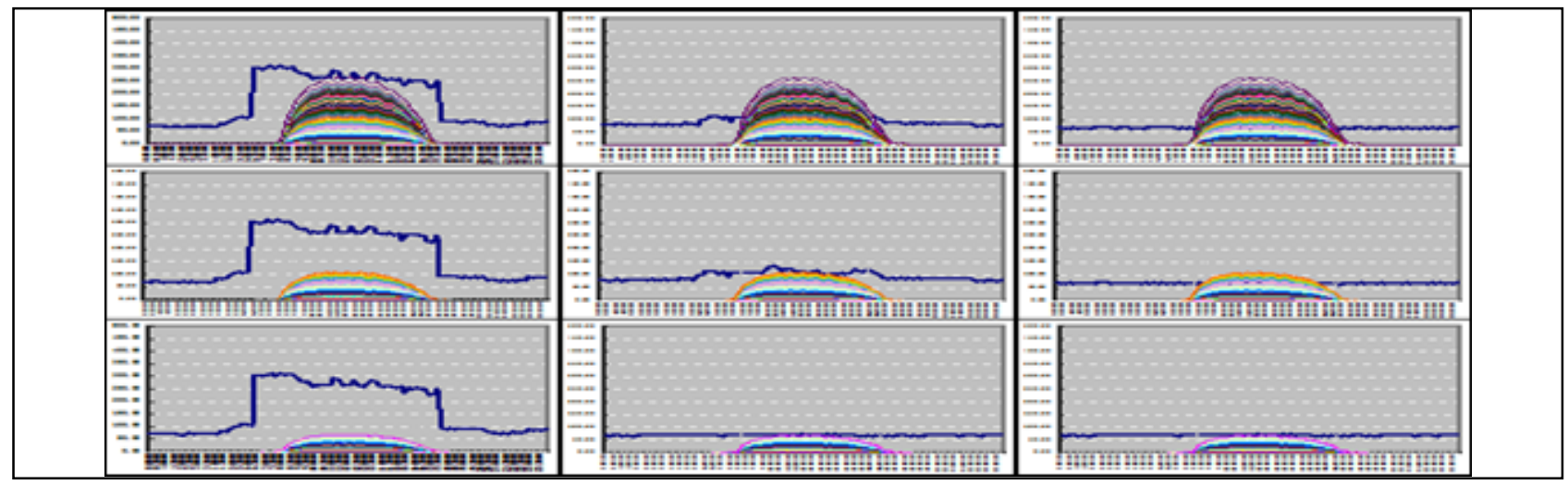

Figure 8. Matching of power load curves

\section{B. Reasonable Installed Capacity of Commercial Office Building}

In this program, electricity accessing grid is not expected in any case. The load curve on holiday should be used to make ratio with the input and output power curve. Maximal installed capacity get in this way is $390 \mathrm{kWp}$, meanwhile, annual generated energy is about $389796 \mathrm{kWh}$ based on area under the curve of power load, the possible generated energy is only $82 \mathrm{kWh}$.

The actual installed capacity of this program is $30 \mathrm{kWp}$, and most of it was belonged to the available area of roof. From the results of calculating on matching, generated energy was only about $82 \mathrm{kWh}$ even if installed capacity increase 13 times, nearly no generated energy.

Thus for the similar business buildings, photovoltaic available installed area is much smaller relatively to the electricity consumption in any time. It is the best to use the maximal available installed area for photovoltaic cells' installed capacity.

\section{CONCLUSIONS}

Nowadays, most photovoltaic system at home is a little bit monotonous at the configuration of the installed capacity. The largest installed capacity allowed and met the requirements of clients is the only consideration. but whether the configuration is reasonable and power load matches are nearly taken into no consideration.

This paper analyzed the variation of power load, summarized its typical mode. In order to find out a more reasonable way for configuration, we take photovoltaic power supply and loading capacity into consideration comprehensively based on the operating data of this project. The installed capacity calculated in this method is more suited for the reality compared with the traditional configuration.

\section{REFERENCES}

[1] Shinichi Kato.solar power generation can win about 137 billion US dollars in the world market in 2020[N].Mega solar business, pp.0608.2014 .

[2] Shinichi Kato. The solar power system cost undervalued 3 times in 20 years[N].Giant solar business, pp.35-40.2014.

[3] National Energy Bureau.Notice on the implementation scheme of the construction of photovoltaic power generation in 2015[Z], 2015.

[4] Li Xingwen,Li Ting,Feng Zhiwei.Photovoltaic cells' Maximum Power Tracking Point[J].applied sciences,Volume 37 No.6,pp.3537.2010-06. 